\title{
PENGEMBANGAN BUKU AJAR MATA KULIAH BAHASA INDONESIA BERBASIS PEMBELAJARAN KOOPERATIF UNTUK PENGUATAN KARAKTER MAHASISWA FAKULTAS TARBIYAH DAN KEGURUAN UIN STS JAMBI
}

\author{
Mursyid, Yuli Amaliyah \\ UIN STS Jambi \\ mursyid.uin17@gmail.com, yuliamaliyah405@yahoo.com
}

\begin{abstract}
ABSTRAK
Penelitian ini bertujuan untuk memperoleh kevalidan, kepraktisan dan kemenarikan untuk produk pengembangan buku ajar mata kuliah bahasa indonesia berbasis pembelajaran kooperatif untuk penguatan karakter mahasiswa Fakultas Tarbiyah Dan Keguruan UIN STS JAMBI disusun kedalam bentuk buku ajar. Langkah-langkah yang dilakukandalampenelitianinimengikutilangkah-langkah Model Dick, Carrey \& Carrey (2009) yang disederhanakanmenjadisembilandarisepuluhlangkah yang ada. Instrumen yang digunakandalampenelitianiniyaituangketvalidasiahlimangketkepraktisandaritemansejawatdanu jikemenarikandarimahasiswa. Dari hasilujikelayakanprodukpengembanganpadahasil uji validasi ahli mendapat skor presentase sebesar $84,62 \%$, produk yang sudah dikembangkan sangat layak untuk digunakan. Ujikepraktisanberdasarkanhasil tanggapan dosen terhadap modul belajar sebesar $90 \%$, produk yang dikembangkan masuk dalan kategori kriteria digunakan tanpa revisi. Padaujikepraktisanmelaluitanggapan perserta didik diperoleh hasil dengan presentase ratarata sebesar 75,16\%, hasil tersebut berada pada tingkat kualifikasi layak.
\end{abstract}

Kata Kunci: Pembelajarankooperatif, PendidikanKarakter

\section{ABSTRACT}

This study aims to obtain validity, practicality and attractiveness for the product of the development of Indonesian language course textbooks based on cooperative learning to strengthen the character of students of the Faculty of Tarbiyah and Teacher Training at UIN STS JAMBI in the form of textbooks. The steps taken in this study follow the steps of Model Dick, Carrey \& Carrey which are simplified into nine out of ten steps. The instruments used in this study were the ahlim validity questionnaire validation questionnaire from peers and the attractiveness test of the students. From the results of the product development feasibility test on the results of the expert validation test, the percentage score is $84.62 \%$, the product that has been developed is very feasible to use. Practical test based on the results of lecturer responses to the learning module by $90 \%$, products developed in the criteria category are used without revision. In the practicality test through student responses obtained results with an average percentage of $75.16 \%$, the results are at a decent level of qualification.

Keywords: Cooperative Learning, Character Education

\section{PENDAHULUAN}

Pendidikan Bahasa Indonesia

diberikan pada seluruh jenjang pendidikan dari tingkat sekolah dasar hingga perguruan tinggi. Pendidikan Bahasa Indonesia pada masingmasing jenjang ini memiliki tujuan yang berbeda satu sama lain. Perbedaan ini bukan sekadar dalam hal materi melainkan juga berkenaan dengan gradasi keterampilan yang harus dimiliki. Berdasarkan gradasinya arah pendidikan Bahasa Indonesia pada semua jenjang 
pendidikan adalah sama yaitu mencapai tujuan pendidikan sebagaimana tercantum dalam kurikulum yang berlaku.

Mata kuliah Bahasa Indonesia adalah salah satu mata kuliah di perguruan tinggi yang diharapkan dapat melatih mahasiswa untuk memperoleh keterampilan berBahasa Indonesia, terutama dalam ragam tulis akademik dan presentasi ilmiah sebagai alat untuk mempelajari keilmuannya. Mata kuliah Bahasa Indonesia merupakan pelajaran yang mengembangkan kemampuan mahasiswa dalam berBahasa Indonesia dengan baik dan benar, karena penguasaan atas Bahasa Indonesia dapat dijadikan ukuran nasionalisme seseorang sebagai bangsa Indonesia. Selain itu, mata kuliah ini juga bertujuan untuk mengembangkan kemampuan mahasiswa dalam mengorganisasi ide-ide atau konsep-konsep untuk dikomunikasikan kepada pihak lain sehingga terjalin interaksi antaride yang berkesinambungan dan menghasilkan proses transfer ilmu dan pengelolaan yang berjalan efektif (Dikti, 2013: i).

Sebagai bahan pembelajaran, materi Bahasa Indonesia harus diajarkan dengan memperhatikan ciri serta syarat kebakuan bahasa, baik sebagai ragam lisan maupun ragam tulis, dan Bahasa Indonesia sebagai bahasa ilmu pengetahuan serta bahasa kebudayaan yang berfungsi sebagai bahasa modern. Menurut
Kurniady (2008: 26-27) sebagai bahasa pengantar, penalaran, dan pengungkap pengembangan diri Bahasa Indonesia yang digunakan di lembaga pendidikan harus mempunyai ciri-ciri sebagai berikut: (1) mempunyai kemampuan menjalankan tugas sebagai alat komunikasi yang efektif dan efisien, yaitu memiliki kemampuan menyajikan informasi secara tepat dengan berbagai konotasi; (2) memiliki bentuk esistensi; (3) memiliki keluwesan sehingga dapat dipergunakan untuk mengekspresikan makna-makna baru, dan (4) memilikiragam yang sesuai dengan jenjang lembaga pendidikan tempat Bahasa Indonesia digunakan.

Namun pada kenyataannya, dalam pelaksanaan perkuliahan Bahasa Indonesia cenderung lebih mengajarkan tentang teori-teori kebahasaan daripada melatih mahasiswa untuk menggunakan Bahasa Indonesia sebagai bahasa untuk mempelajari ilmu pengetahuan. Artinya, mata kuliah Bahasa Indonesia belum optimal melatih keterampilan berbahasa mahasiswa, terutama pada aspek menulis dan berbicara. Selain itu, selama ini pembelajaran Bahasa Indonesia masih bersifat kurikulum sentris, yaitu sebatas pada pencapaian keterampilan berbahasa sebagaimana yang terdapat dalam SK/KD yang telah ditentukan, tanpa dikembangkan pada unsur-unsur 
pendidikan nilai yang sesungguhnya sangat diperlukan peserta didik. Oleh karena itu, perlu adanya pembaharuan dan perbaikan dalam proses pembelajaran Bahasa Indonesia.

Kendala yang dihadapi oleh mahasiswa di Fakultas Tarbiyah dan IImu Keguruan adalah belum tersedianya buku ajar Bahasa Indonesia sebagai pendukung perkuliahan serta yang dapat mengintegrasikan pendidikan karakter di dalamnya. Para pemerhati pengguna Bahasa Indonesia termasuk dosen sering mengeluhkan pemakaian Bahasa Indonesia oleh para mahasiswa yang masih rendah. Banyak mahasiswa yang kurang mampu menggunakan Bahasa Indonesia dengan baik dan benar ketika menulis maupun mempresentasikan karya ilmiahnya, bahkan dalam komunikasi sehari-hari pun masih terlihat buruk.

Hal tersebut terlihat masih rendahnya pendidikan karakter yang tertanam pada diri mahasiswa. Pengembangan pendidikan karakter di perguruan tinggi dapat diintegrasikan dalam pendidikan pada setiap mata kuliah. Materi pendidikan yang berkaitan dengan norma atau nilai-nilai pada setiap mata kuliah perlu dikembangkan, dieksplisitkan, dikaitkan dengan konteks kehidupan sehari-hari. Pendidikan nilai-nilai karakter tidak hanya pada tataran kognitif, tetapi menyentuh pada internalisasi, dan pengalaman nyata dalam kehidupan mahasiswa di masyarakat. Pendidikan karakter di perguruan tinggi merupakan upaya menumbuhkembangkan karakter mahasiswa sebagai kelanjutan pengembangan karakter di jenjangjenjang pendidikan sebelumnya.

Pendidikan yang berorientasi pada pembentukan karakter bangsa dapat diwujudkan melalui pengoptimalan peran bahasa. Bahasa Indonesia dapat membangun karakter bangsa dengan membedakan persepsi antara pengajaran dan pendidikan Bahasa Indonesia. Pengajaran Bahasa Indonesia adalah pengajaran mengenai teks berBahasa Indonesia yang meliputi mulai dari ejaan, kosakata, kalimat hingga wacana. Pendidikan Bahasa Indonesia adalah fokus terhadap peserta didik yang belajar Bahasa Indonesia. Kecenderungan yang terjadi pada pembelajaran Bahasa Indonesia selama ini adalah belajar mengenai bahasa dan kurang mendalami belajar bahasa dan belajar melalui bahasa. Belajar melalui bahasa berarti mendengar untuk belajar, berbicara untuk belajar, membaca untuk belajar, dan menulis untuk belajar. Di dalam mempraktikkan semua keterampilan berbahasa tersebut diperlukan suatu sikap santun sebagai bagian dari pengembangan karakter (Setyawati, 2013: 742-743). 
Berkaitan

dengan

pengintegrasian pendidikan karakter dalam mata kuliah Bahasa Indonesia bukanlah hal yang sukar diterapkan. Hal ini disebabkan dalam mata kuliah Bahasa Indonesia terdapat empat keterampilan berbahasa yaitu keterampilan menyimak, berbicara, membaca, dan menulis. Keempat keterampilan itu menjadi standar kompetensi yang telah ditetapkan dalam kurikulum yang berlaku saat ini. Pencapaian standar kompetensi melalui sajian kompetensikompetensi dasar di jenjang pendidikan tinggi ini mensyaratkan setiap mahasiswa memperoleh pengalaman belajar dengan berlatih menggunakan keempat keterampilan berbahasa tersebut untuk membentuk kepribadian yang unggul (Andayani, 2013: 56).

Pendidikan Bahasa Indonesia memiliki peranan yang sangat penting bukan hanya untuk membina keterampilan komunikasi melainkan juga untuk kepentingan penguasaan ilmu pengetahuan. Melalui bahasalah manusia belajar berbagai macam pengetahuan yang ada di dunia. Pendidikan bahasa haruslah diorientasikan pada pembentukan kemampuan berbahasa dan pembentukan kemampuan keilmuan yang lain. Atas dasar dua orientasi pokok ini, pendidikan bahasa harus dikembangkan menjadi pendidikan yang multifungsi melalui penciptaan pendidikan yang harmonis, bermutu, dan bermartabat (Abidin, 2012: 6).
Pendidikan karakter hendaknya diintegrasikan ke dalam mata pelajaran yang relevan, dan juga diintegrasikan ke dalam tatanan kehidupan dan iklim sosial-budaya dunia pendidikan. Integrasi pendidikan karakter ke dalam mata pelajaran Bahasa Indonesia berkait dengan konsep kesantunan berbahasa. Aspek kesantunan merupakan hal penting dalam berbahasa maupun dalam kegiatan berkomunikasi secara luas. Aspek kesantunan sering menjadi bahan kajian, baik dalam praktik berbahasa secara umum dan terutama kesantunan berbahasa dalam dunia pendidikan (Subyantoro, 2011: 513).

Berdasarkan uraian di atas, perlu ditegaskan kembali bahwa pendidikan Bahasa Indonesia diarahkan untuk mencapai beberapa tujuan yang harus dimiliki peserta didik, yakni kemampuan berbahasa, sikap berbahasa, pengetahuan tentang ilmu kebahasaan Bahasa Indonesia, kesadaran diri atas pentingnya karya sastra bagi pengembangan diri, sikap positif peserta didik terhadap karya sastra. Muara dari tujuan ini adalah peserta didik (mahasiswa) mampu berkomunikasi secara berkarakter.

$$
\text { Oleh karena itu, dapat }
$$
dinyatakan bahwa permasalahan pendidikan karakter yang terkait dengan buku ajar yang digunakan oleh mahasiswa untuk meningkatkan keaktifan dan kerja sama mahasiswa dalam pendidikan, maka perlu 
dikembangkan secara operasional dan prosedural sehingga mudah diimplementasikan di perguruan tinggi melalui penelitian yang berjudul "Pengembangan Buku Ajar Mata Kuliah Bahasa Indonesia Berbasis Pembelajaran Kooperatif untuk Penguatan Pendidikan Karakter Mahasiswa Fakultas IImu Tarbiyah.

Adapun tujuan penelitian ini yaitu: (a)untuk mengetahui prosedur penelitian dan pengembangan Buku ajar mata kuliah Bahasa Indonesia berbasis pembelajaran kooperatif untuk penguatan pendidikan karakter mahasiswa Fakultas Tarbiyah dan Keguruan UIN STS Jambi, (b)untuk mengetahui kevalidan Buku ajar mata kuliah Bahasa Indonesia berbasis pembelajaran kooperatif untuk penguatan pendidikan karakter mahasiswa Fakultas Tarbiyah dan Keguruan UIN STS Jambi, (c) untuk mengetahui kepraktisan Buku ajar mata kuliah Bahasa Indonesia berbasis pembelajaran kooperatif untuk penguatan pendidikan karakter mahasiswa Fakultas Tarbiyah dan Keguruan UIN STS Jambi.

\section{METODE PENELITIAN}

Model penelitian dan pengembangan yang digunakan dalam penelitian ini yaitu model Dick, Carrey \& Carrey (2009: 6-8). Langkahlangkah penelitian dan pengembangan Model Dick, Carrey \& Carrey (2009: 6-8) yaitu: 1)mengidentifikasi tujuan pembelajaran, 2)melakukan analisis pembelajaran dan ketrampilan bawahan, 3) menganalisis pebelajar dan lingkungan, 4)merumuskan tujuan khusus, 5)mengembangkan instrumen

6)mengembangkan

penilaian, pembelajaran, 7)mengembangkan dan memilih materi pembelajaran, 8)mendesain dan melakukan evaluasi formatif, 9)merevisi bahan pembelajaran, dan 10)mendesain dan melakukan evaluasi sumatif.

\section{HASIL PENELITIAN DAN \\ PEMBAHASAN \\ Hasil}

1. Data Uji Validasi Ahli

Uji validasi materi adalah kegiatan penilaian yang dilakukan oleh ahli materi, yang dilihat dalam hal ini yaitu sejauh mana kedalaman materi serta ketepatan isi di dalam Buku Ajar Mata Kuliah Bahasa Indonesia Berbasis Pembelajaran Kooperatif untuk Penguatan Pendidikan Karakter yang dikembangkan.

Tabel 1. Hasil Uji Validasi Ahli

\begin{tabular}{|c|c|c|}
\hline No. & Aspek Yang dinilai & $\begin{array}{c}\text { Jumlah } \\
\text { Nilai }\end{array}$ \\
\hline 1 & Tujuan dan Pendekatan & 35 \\
\hline 2 & Desain dan Organisasi & 33 \\
\hline 3 & Konten Kebahasaan & 22 \\
\hline 4 & Metodologi & 41 \\
\hline 5 & Pertimbangan praktis & 34 \\
\hline \multirow{2}{*}{\multicolumn{2}{|c|}{ Total Skor Perolehan }} & 165 \\
\hline & & $84,62 \%$ \\
\hline
\end{tabular}

Presentase $=\frac{\text { Total Skor Perolehan }}{\text { Skor Maksimal }} \times 100 \%$ 
Skor perolehan pada tahap uji validasi ahli diperoleh skor sebesar 84,62\%. Berdasarkan kriteria kelayakan produk, hasil uji validasi dengan kualifikasi sangat layak. Sehingga produk yang dikembangkan dapat digunakan tanpa revisi. Meskipun demikian, beberapa catatan berupa saran dan komentar dijadikan sebagai landasan untuk dilakukan revisi untuk digunakan pada tahap selanjutnya.

\section{Data Tanggapan Teman Sejawat}

$$
\text { Data tanggapan teman }
$$
sejawat diperlukan dalam proses pengembangan ini untuk mengetahui kepraktisan produk yang sudah dikembangkan. Informasi dari teman sejawat digunakan sebagai rujukan dalam melakukan revisi produk untuk disesuaikan dengan teori dalam proses pembelajaran melalui pengumpulan angket yang diberikan peneliti pada teman sejawat.

Tabel 2. Hasil Penilaian Tanggapan Teman Sejawat

\begin{tabular}{|c|c|c|}
\hline No. & Aspek Yang dinilai & $\begin{array}{c}\text { Jumlah } \\
\text { Nilai }\end{array}$ \\
\hline 1 & Tujuan Pembelajaran & 44 \\
\hline 2 & Komponen Bahasa & 16 \\
\hline 3 & $\begin{array}{c}\text { Struktur dan Organisasi } \\
\text { Konten }\end{array}$ & 38 \\
\hline 4 & $\begin{array}{c}\text { Penguatan Pendidikan } \\
\text { Karakter }\end{array}$ & 9 \\
\hline 5 & $\begin{array}{c}\text { Pengembangan } \\
\text { Keterampilan Bahasa }\end{array}$ & 19 \\
\hline 6 & Keterajaran (Teach-ability) & 8 \\
\hline
\end{tabular}

\begin{tabular}{|c|c|c|}
\hline No. & Aspek Yang dinilai & $\begin{array}{c}\text { Jumlah } \\
\text { Nilai }\end{array}$ \\
\hline & dan Fleksibilitas (Flexibility) & \\
\hline 7 & Strategi Pembelajaran & 16 \\
\hline 8 & Preparedness dan Penilaian & 14 \\
\hline & $\begin{array}{c}\text { Total Skor Perolehan } \\
(1+2+3+4+5)\end{array}$ & 164 \\
\hline & Skor Maksimal $(5 \times 21)$ & 180 \\
\hline & Presentase Perolehan $(\%)$ & $91 \%$ \\
\hline
\end{tabular}

Hasil perolehan hasil tanggapan teman sejawat terhadap modul belajar sebesar 90\%. Hasil tersebut di konversi berada pada kualifikasi sangat layak. Dengan demkian, produk yang dikembangkan masuk dalan kategori kriteria digunakan tanpa revisi.

\section{Data TanggapanMahasiswa}

Hasil perolehan uji lapangan terbatas melalui tanggapan perserta didik diperoleh hasil dengan presentase rata-rata sebesar 75,16\%. Setelah dikonversi, hasil tersebut berada pada tingkat kualifikasi layak. Dengan demikian produk modul belajar yang digunakan berkreteria dapat digunakan namun perlu revisi.

Setelah uji coba telah semua dilaksanakan, tahap selanjutnya melakukan revisi produk berdasarkan catatan berupa saran dan komentar yang muncul. Setelah itu, barulah kemudian produk yang sudah direvisi dapat dipergunakan sebagai upaya meningkatkan keterampilan dasar mengajar guru. 
Pembahasan

Pengembangan Buku Ajar mata kuliah Bahasa Indonesia Berbasis Pembelajaran Kooperatif untuk Penguatan Pendidikan Karakter Mahasiswa Fakultas Tarbiyah dan Keguruan UIN STS Jambi ini bertujuan untuk mengetahui tingkat kelayakan produk pengembangan berupa pengembangan bahan ajar yang disusun ke dalam sebuah buku ajar. Analisis kelayakan produk modul belajar sudah mendapatkan kualifikasi sangat layak dari hasil uji validasi ahli. Sehingga produk yang dikembangkan dapat digunakan tanpa revisi.

Buku ajar mata kuliah bahasa Indonesia terdiri dari lima bab yaitu bab pertama mengeksplorasi teks akademik dalam gere makro, bab kedua menjelajah dunia pustaka, bab tiga mendesain proposal penelitian dan proposal kegiatan, bab empat melaporkan hasil penelitian dan hasil kegiatan, dan bab lima mengaktualisasikan diri melalui artikel ilmiah.

Skor perolehan yang dari hasil uji validasi ahli mendapat skor presentase sebesar $84,62 \%$. Dengan demikian, skor perolehan yang diperoleh dari hasil uji validasi ahli dinyatakan bahwa produk yang sudah dikembangkan sangat layak untuk digunakan. Kelayakan produk tersebut dapat ditinjau berdasarkan: (a) Tujuan dan Pendekatan; (b) Desain dan Organisasi; (c) Konten
Kebahasaan; (d) Metodologi; dan (e) Pertimbangan kepraktisan.

Kelayakan produk yang sudah divalidasi selanjutnya, melakukan uji coba lapangan terbatas yang melibatkan dosen dan peserta didik yang mengontrak mata kuliah Bahasa Indonesia. Kelayakan produk pada uji coba ini meliputi tanggapan teman sejawat dan peserta didik dalam menggunakan buku ajar mata kuliah bahasa Indonesia berbasis pembelajaran kooperatif untuk penguatan pendidikan karakter mahasiswa. Kelayakan modul belajar berdasarkan tanggapan dosen dengan perolehan hasil tanggapan dosen terhadap buku ajar sebesar 90\%. Hasil tersebut di konversi berada pada kualifikasi sangat layak. Dengan demkian, produk yang dikembangkan masuk dalan kategori kriteria digunakan tanpa revisi.

Sedangkan kriteria kelayakan buku berdasarkan tanggapan peserta didik ditinjau berdasarkan: (a) Kelayakan Isi (Konten); (b) Kelayakan Penyajian;dan (c) Kelayakan Bahasa. Hasil perolehan uji lapangan terbatas melalui tanggapan perserta didik diperoleh hasil dengan presentase rata-rata sebesar $75,16 \%$. Setelah dikonversi, hasil tersebut berada pada tingkat kualifikasi layak. Dengan demikian produk modul belajar yang digunakan berkreteria dapat digunakan namun perlu revisi.

Hasil Pengembangan Buku Ajar Mata Kuliah Bahasa Indonesia Berbasis Pembelajaran Kooperatif 
untuk Penguatan Pendidikan Karakter Mahasiswa Fakultas Tarbiyah dan Keguruan UIN STS Jambi telah mengahasilkan buku ajar yang memenuhi karakteristik modul belajar yang baik sesuai dengan pendapat Daryanto (2013:9), yaitu sebagai berikut: 1)Self Intruction, karena buku ajar memuat tujuan pembelajaran yang jelas, dan dapat menggambarkan kompetensi yang akan dicapai, berbasis pembelajaran kooperatif, memuat materi pembelajaran yang dikemas dalam unit-unit kegiatan yang kecil dan spesifik, sehingga mudah dipelajari secara tuntas, tersedia contoh dan ilustrasi yang mendukung kejelasan pemaparan materi pembelajaran, terdapat soal-soal latihan, tugas dan sejenisnya yang memungkinkan untuk mengukur penguasaan peserta didik, kontekstual yaitu materi yang disajikan terkait dengan suasana, tugas atau konteks kegiatan dan lingkungan peserta didik, menggunakan bahasa yang sederhana dan komunikatif, terdapat rangkuman materi pembelajaran, terdapat aturan penilaian yang memungkinkan peserta didik dapat melakukan penilaian diri, terdapat informasi tentang rujukan/pengayaan/referensi yang mendukung materi yang dimaksud serta memberi penguatan karakter baik untuk mahasiswa pada setiap bahan materi dan kegiatannya. 2)Self Contained, karena seluruh materi bahasa Indonesia keilmuan termuat buku ajar tersebut. 3)Stand Alone, karena buku tidak tergantung pada bahan ajar/media lain, tidak harus digunakan bersama-sama dengan bahan ajar/media lain. 4)Adaptive, karena dapat menyesuaikan dengan perkembangan ilmu pengetahuan dan teknologi, secara fleksibel/luwes digunakan diberbagai perangkat keras (hardware). 5)Bersahabat/Akrab (User Friendly) karena setiap instruksi dan paparan informasi yang ditampilkan bersifat membantu dan bersahabat dengan pemakainya, mudah pemakai dalam merespon dan mengakses sesuai dengan keinginan, penggunaan bahasa yang sederhana dan mudah dimengerti, menggunakan istilah yang umum digunakan.

\section{KESIMPULAN}

Hasil Pengembanganbuku ajar mata kuliah bahasa Indonesia berbasis pembelajaran kooperatif untuk penguatan mahasiswa FTK UIN STS Jambi telah mengahasilkan buku yang memenuhi karakteristik buku ajar yang baik dengan kriteria yang baik.

\section{SARAN}

Lebih lanjut agar produk pengembangan yang dihasilkan dapat dimanfaatkan untuk kalangan lebih luas dengan penyesuaian terutama penyesuaian pada karakteristik peserta didik sebagai pengguna. 


\section{DAFTAR PUSTAKA}

Abidin, Yunus. 2012. Pembelajaran Bahasa Berbasis Pendidikan Karakter. Bandung: Refika Aditama.

Daryanto, D. (2013). "Media Pembelajaran Peranannya Sangat Penting Dalam Mencapai Tujuan Pembelajaran". Yogyakarta: Gava Media.

Dick, W. and Carey, L. Carey, J.O. 2009. The Systematic Design of Intruction. Seventh Edition. New Jersey: Person.

Direktorat Jenderal Pendidikan Tinggi Kementerian Pendidikan dan Kebudayaan Republik Indonesia 2013.

Kurniady, H. Kunkun. 2008. "Pemanfaatan Model Pembelajaran Menulis Karya Ilmiah secara Kolaboratif dengan Menggunakan Teknik Portofolio dalam Mata Kuliah Umum Bahasa Indonesia". Disertasi. Bandung: Universitas Pendidikan Indonesia.

Peraturan Menteri pendidikan nasional Republik indonesia Nomor 16 tahun 2007 tentang standar kualifikasi akademik dan kompetensi guru.

Samani, M. \& Hariyanto. 2012. Konsep dan Model Pendidikan Karakter. Bandung: PT Remaja Rosdakarya.

Setyawati, Rukni. 2013. "Peranan Bahasa Indonesia Sebagai Sarana Membangun Karakter Bangsa" hal 741-744. Dalam Saddhono, dkk. (Ed). Proceeding Seminar
Internasional Pengembangan Peran Bahasa dan Sastra Indonesia untuk Mewujudkan Generasi Berkarakter. Surakarta: UNS.

Subyantoro, dkk. 2011. Prosiding Bahasa dan Sastra Indonesia konservasi dan Pendidikan Karakter. Semarang Kepl Press. 